\title{
GERMINATION AND OSMOTIC ADJUSTMENT IN Salvia hispanica L. (LAMIACEAE) SEEDLINGS UNDER WATER AND THERMAL STRESS
}

\author{
GERMINAÇÃO E AJUSTAMENTO OSMÓTICO EM PLÂNTULAS DE Salvia \\ hispanica L. (LAMIACEAE) SOB ESTRESSE HÍDRICO E TÉRMICO \\ Emanoela Pereira de PAIVA ${ }^{1^{*}}$; Salvador Barros TORRES ${ }^{1}$; \\ Renata Ramayane Torquato OLIVEIRA ${ }^{1}$; Francisco Vanies da Silva SÁ $^{\mathbf{1}}$; \\ Moadir de Sousa LEITE ${ }^{1}$; Tatianne Raianne Costa ALVES ${ }^{1}$; Daniela Marques de OLIVEIRA ${ }^{1}$ \\ 1. Universidade Federal Rural do Semi-Árido, Mossoró, RN, Brasil. emanuelappaiva@hotmail.com*
}

\begin{abstract}
Salvia hispanica seedlings have stood out for their potentialities in nutrients for agrifood industries. Nevertheless, studies related to this species are still scarce, especially with respect to agronomic factors that enable its propagation and development. Hence, this study aimed to evaluate germination, vigor and osmotic adjustment of S. hispanica seeds and seedlings subjected to water and thermal stress. The experimental design was completely randomized, with treatments arranged in factorial scheme, corresponding to five levels of polyethylene glycol (PEG 6000) $(0.0 ;-0.1 ;-0.2 ;-0.3$ and $-0.4 \mathrm{MPa}$ ) and five temperatures $\left(20,25,30\right.$ and $\left.20-30{ }^{\circ} \mathrm{C}\right)$, with four replicates of 50 seeds in each treatment. Germination test was set on blotter paper, moistened with PEG 6000 solutions at the previously mentioned potentials, under 8-h photoperiod. The following variables were analyzed: germination, germination speed index, seedling shoot length, seedling root length, seedling dry matter and contents of chlorophyll, carotenoids, amino acids, proline and sugars. Polyethylene glycol levels of $-0.4 \mathrm{MPa}$ at all temperatures and $-0.3 \mathrm{MPa}$ at $30{ }^{\circ} \mathrm{C}$ and $20-30{ }^{\circ} \mathrm{C}$ enable germination and vigor of $S$. hispanica seedlings. $S$. hispanica seedlings are able to perform osmotic adjustment under water stress conditions up to the level of $-0.3 \mathrm{MPa}$, when grown from seeds germinated at temperatures of up to $25^{\circ} \mathrm{C}$.
\end{abstract}

KEYWORDS: Chia. Polyethylene glycol. Abiotic stress. Viability.

\section{INTRODUCTION}

Salvia hispanica $\mathrm{L}$. is native to western and central Mexico and Guatemala and its seeds have stood out for being a potential source of nutrients for agri-food industries and for their beneficial properties for health (MUÑOZ et al., 2012). Considering a possible increase in the cultivation and commercialization of this species in Brazil, evaluating seed quality is essential for the success of the crop.

A successful plant establishment at the field depends mostly on seed germination conditions (GORAI; GASMI; NEFFATI, 2011). Studies related to the germination response of seeds to artificial stress conditions are especially important for plant physiology and ecophysiology, and can be used as a tool to identify limits of tolerance, of survival and adaptation of the species to stressful conditions (GUEDES et al., 2013).

Seed germination is a process that requires water and heat, and, depending on species, other factors are necessary, such as oxygen and light (MARCOS FILHO, 2015). Water availability directly affects germination, since water absorption triggers a series of physical, physiological and biochemical processes inside the seed, such as activation of enzymes, breakage of chemical bonds and translocation and use of stored substances (BEWLEY et al., 2013). As noted, temperature interferes with water absorption dynamics and with limits and speed of biochemical reactions, besides physiological processes that determine the germination process (CARVALHO; NAKAGAWA, 2012).

Changes of temperature can affect the processes controlling seed germination, including the permeability of membranes and activity of cytosolic and membrane-bound enzymes (MARAGHNI; GORAI; NEFFATI, 2010). Therefore, germination will be faster and more efficient as temperature increases, respecting the limit of each species, called Cardinal temperatures. Gradual reduction of temperature causes accentuated decrease in germination speed and the under these conditions may lead to reduction in seedling growth, even when temperature returns to favorable levels (MARCOS FILHO, 2015). In $S$. hispanica seeds, Labouriau; Agudo (1987) observed that the extreme limits of temperature are $3.3 \pm 0.4$ 
${ }^{\circ} \mathrm{C}$ and $39.8 \pm 0.4{ }^{\circ} \mathrm{C}$, demonstrating that low temperatures limit seed germination, even when close to the lower limits of some cold-tolerant tropical plants.

Another limiting factor for germination is water deficit and, for each species, there is a value of external water potential below which germination does not occur (ÁVILA et al., 2007). A study conducted by Yamashita; Guimarães (2010) found that germination and germination speed of Conyza canadensis and Conyza bonariensis seeds are reduced as water availability decreases in the substrate, from -0.15 MPa on. Guedes et al. (2013) observed that germination percentage of Apeiba tibourbou seeds was significantly reduced from the water potential of $-0.2 \mathrm{MPa}$, reaching $51 \%$ at temperature of $30^{\circ} \mathrm{C}$ and, at $25^{\circ} \mathrm{C}$, seed germination capacity was more affected, reaching $37 \%$.

Therefore, this study aimed to evaluate germination, vigor and osmotic adjustment of $S$. hispanica seeds and seedlings subjected to water and thermal stress.

\section{MATERIAL AND METHODS}

The experiment was conducted at the Federal Rural University of the Semi-Arid Region, Mossoró- RN (5'12'48' latitude and 37'18'44', longitude, at $37 \mathrm{~m}$ of altitude). S. hispanica seeds used in the study came from a commercial production field, located in the municipality of Santana do Livramento, Rio Grande do Sul (30 $53^{\circ}$, $27^{\prime \prime} \mathrm{S} ; 55^{\circ} 31$ ' 58" W; $208 \mathrm{~m}$ ). Seeds were manually processed, placed in transparent plastic bags $(0.15$ mm thick) and stored in cold and dry chamber (10 \pm $2{ }^{\circ} \mathrm{C}$ and $50 \%$ of relative humidity of the environment) during the experimental period.

The statistical design was completely randomized in $5 \times 4$ factorial scheme (osmotic potentials $\mathrm{x}$ temperatures), and each treatment was composed of four replicates of 50 seeds.

The seeds were planted on two sheets of blotter paper, which were placed in transparent plastic boxes (Gerbox $\left.{ }^{\circledR}\right)$ and moistened with PEG 6000 solutions, in volume corresponding to 2.5 times the weight of the dry paper. The solutions were produced according to the values proposed by Villela, Doni Filho and Sequeira (1991), to simulate the previously established osmotic potentials of 0.0 , $-0.1,-0.2,-0.3$ and $-0.4 \mathrm{MPa}$.

Germination test was conducted in Biochemical Oxygen Demand (B.O.D.) germinators, regulated at constant temperatures of 20,25 and 30 ${ }^{\circ} \mathrm{C}$, and alternated temperature of $20-30{ }^{\circ} \mathrm{C}$, with $8-\mathrm{h}$ photoperiod. Counts were daily performed until 8 days after sowing, considering as germinated the seeds that had produced primary root and shoots of the seedling (BRASIL, 2009). Simultaneously to the germination test, germination speed index was determined by daily evaluating the seedlings, from the beginning of germination to 8 days after sowing.

At the end of the germination test, all normal seedlings of the experimental unit were measured for root length (collar to root tip) and shoot length (collar to insertion of cotyledons), using a ruler graduated in millimeter. Subsequently, the material was dried in a forced-air oven regulated at $65{ }^{\circ} \mathrm{C}$, until constant weight, and weighed on analytical precision scale $(0.001 \mathrm{~g})$. Total dry matter was determined by the sum of root and shoot dry matter.

Chlorophyll $a$ and $b$ and carotenoids contents were determined by extracting chlorophyll in acetone $(80 \%)$ and quantifying it through spectrophotometry. The absorbance of the samples was measured in spectrophotometer at 470, 646.8 and $663.2 \mathrm{~nm}$, and chlorophyll and carotenoids contents (mg pigment $\mathrm{g}^{-1}$ FM) were obtained according to Lichthenthaler (1987), using the following equations: 1 - chlorophyll $\mathrm{a}=12.25$ ABS663.2 - 2.79 ABS646.8; 2 - chlorophyll b = 21.50 ABS646.8 - 5.10 ABS663.2; 3 - total carotenoids $=(1000$ ABS470 -1.82 chlorophyll a 85.02 chlorophyll b)/198.

At the end of the experiment, fresh matter samples were collected in the seedlings at the different levels of PEG 6000 solutions and thermal stress for the determination of total soluble sugars, total free amino acids and proline. Contents of total soluble sugars were determined by the anthrone method (YEMM; WILLIS, 1954), with results expressed in $\mu \mathrm{mol}$ of GLU $\mathrm{g}^{-1}$ of fresh matter. Amino acids contents were quantified by measuring the absorbance at $570 \mathrm{~mm}$ through the acid ninhydrin method (YEMM; COCKING, 1955), considering glycine as the standard substance, and the results were expressed in $\mu \mathrm{mol}$ TFAA $\mathrm{g}^{-1}$ of matter. Proline quantification followed the methodology described by Bates, Waldren and Teare (1973), with results expressed in $\mu \mathrm{mol}$ PRO g${ }^{1}$ of fresh matter.

The results were subjected to analysis of variance by $F$ test at 0.05 probability level. According to the significance, the data were subjected to polynomial regression analysis ( $\mathrm{p} \leq$

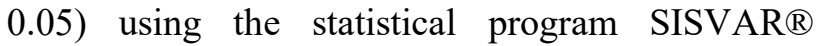
(FERREIRA, 2011). 


\section{RESULTS AND DISCUSSION}

For the interaction between osmotic potentials and temperatures, significant effect occurred on germination, germination speed index, shoot length and root length of $S$. hispanica seedlings at 0.05 probability level (Figure 1). In general, osmotic potentials up to $-0.2 \mathrm{MPa}$ led to germination higher than $70 \%$ at all temperatures,

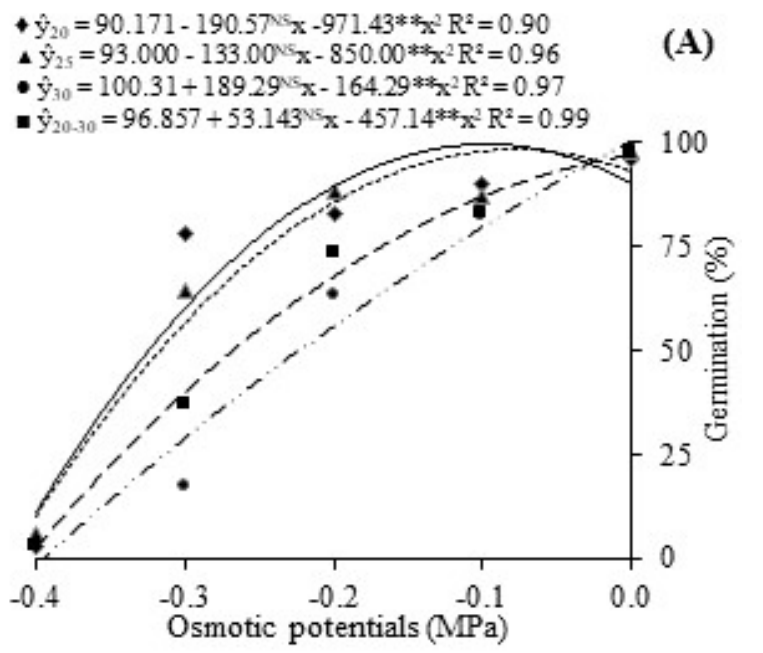

$\leftarrow \hat{y}_{20}=2.4991+6.9804^{06} \mathrm{x}+3.4821 * \mathrm{x}^{2} \mathrm{R}^{2}=0.99$

$\Delta \hat{\mathrm{y}}_{25}=2.8999+14.611^{\mathrm{N5}} \mathrm{x}+20.575 * \mathrm{x}^{2} \mathrm{R}^{2}=0.99$

- $\hat{y}_{30}=3.2261+13.08605 x+14.651 * * x^{2} R^{2}=0.99$

- $\hat{y}_{20-30}=2.7793+13.76405 x+18.988 * * x^{2} R^{2}=0.96$

(C)

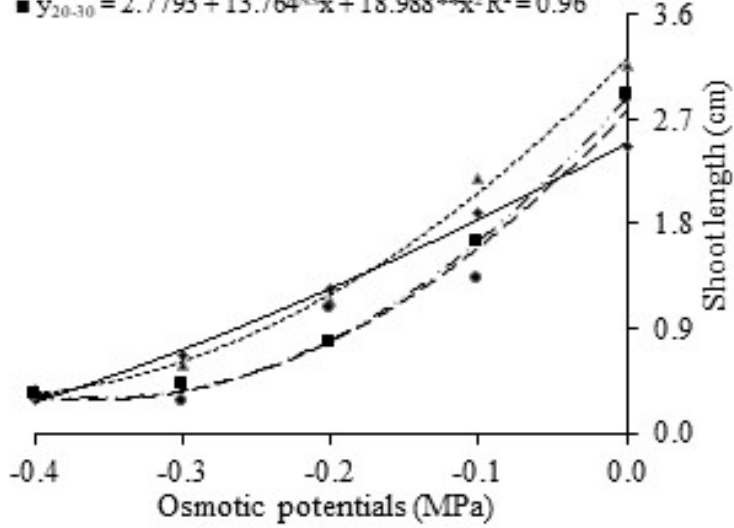

except for seeds germinated at $30{ }^{\circ} \mathrm{C}$, which showed germination of $56 \%$, characterizing water stress from this point on at the highest temperature (Figure 1A). Water stress affected the germination percentage of $S$. hispanica seedlings from the potential of $-0.3 \mathrm{MPa}$ at temperatures of $20,25^{\circ} \mathrm{C}$ and $20-30{ }^{\circ} \mathrm{C}$, eventually leading to values lower than $10 \%$ of normal seedlings at the potential of -0.4 $\mathrm{MPa}($ Figure 1A).
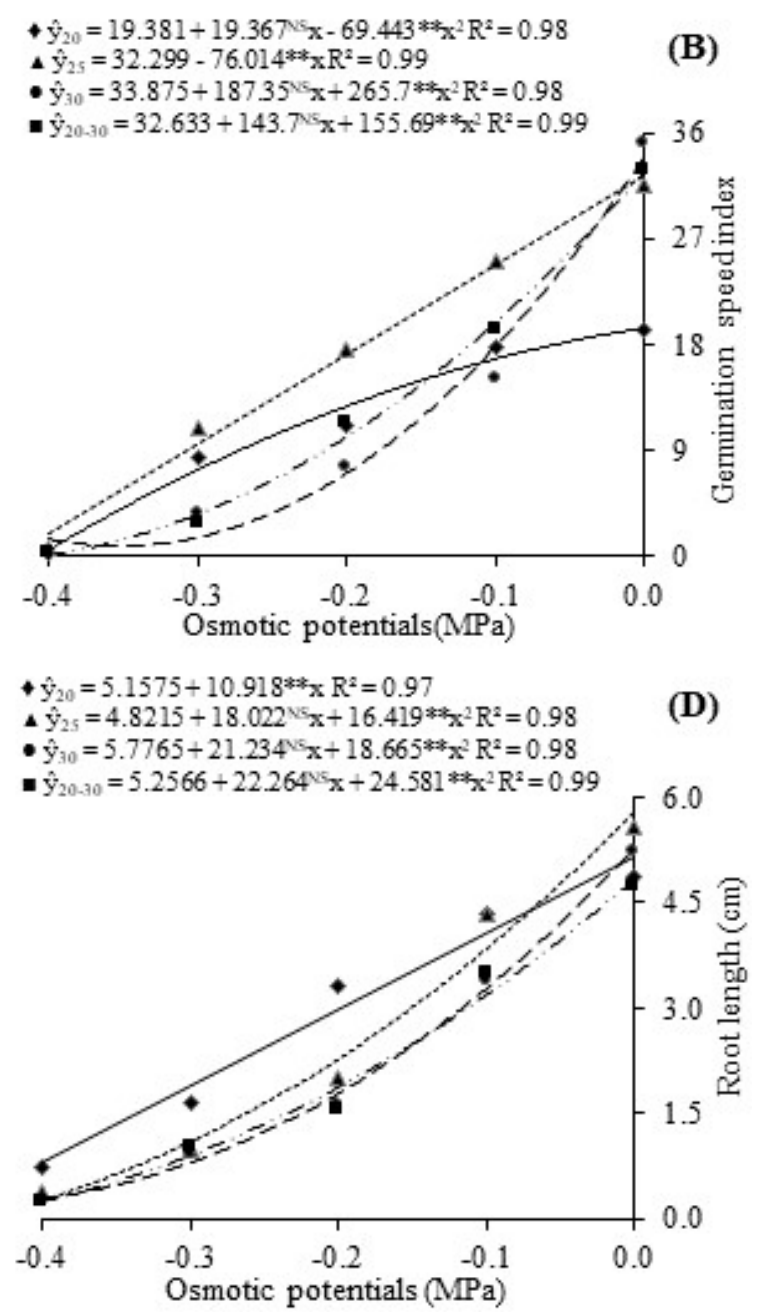

Figure 1. Germination (A), germination speed index (B), shoot length - SL (C) and root length - RL (D) of chia (Salvia hispanica L.) seedlings subjected to different osmotic potentials induced by PEG 6000 , at different temperatures. ${ }^{\mathrm{NS}}$ and $* *=$ not significant and significant at 0.01 probability level $(\mathrm{p}<0.01)$, respectively.

Such reduction in germination, as the osmotic potentials become more negative, is explained by the water restriction, which reduces the speed of metabolic and biochemical processes, delaying or reducing seed germination percentage, interfering with imbibition and cell elongation of the embryo (CARVALHO; NAKAGAWA, 2012). In addition, the reduction in the water potential of the environment influences water absorption and reduces or prevents the emergence of the primary root (GHADERI-FAR; GHEREKHLOO; ALIMOGHOM, 2010). Reduction of germination due to increase in water deficit was also observed by Silva et al. (2014) in land cress (Barbarea verna) seeds. These authors found that the highest temperature $\left(35^{\circ} \mathrm{C}\right)$ led to faster reduction compared with lower ones $\left(20\right.$ and $\left.25^{\circ} \mathrm{C}\right)$. Silva Jr. et al. (2014) also observed that osmotic potentials from $0.4 \mathrm{MPa}$ on significantly reduced the variables 
germination, emergence speed index and length of tomato seedlings.

The highest germination index occurred at temperature of $30{ }^{\circ} \mathrm{C}$ at osmotic potential of 0.0 $\mathrm{MPa}$ (Figure 1B), because high temperatures increase the speed of metabolic processes, shortening the duration of the imbibition phase II. According to Nascimento (2005), very low or very high temperatures can alter both speed and final percentage of germination. Thus, from $-0.1 \mathrm{MPa}$ on, at temperatures of 30 and $20-30{ }^{\circ} \mathrm{C}$, and at $-0.2 \mathrm{MPa}$ at temperatures of 20 and $25{ }^{\circ} \mathrm{C}$ there were accentuated reductions in the germination speed index of $S$. hispanica seeds, eventually reaching values lower than 0.5 at the osmotic potential of -0.4 $\mathrm{MPa}$, regardless of the studied temperature. These results indicate that temperature can increase the intensity of water stress on $S$. hispanica seedlings, as evidenced for the temperatures of $30^{\circ} \mathrm{C}$ and 20 $30{ }^{\circ} \mathrm{C}$, given the accentuated reductions $(>30 \%)$ with a slight oscillation of the osmotic potential from 0.0 MPa to -0.1 MPa.

In studies conducted by Stefanello et al. (2006) with fennel (Foeniculum vulgare) seeds, linear reduction occurred in germination and germination speed, which reached a null value at 0.3 MPa. Jatropha (Jatropha curcas L.) seeds subjected to water stress also suffered reductions in germination and germination speed under water stress, with reduction of more than 10 units from the control to the condition of $-0.2 \mathrm{MPa}$, eventually reaching values close to zero at $-0.8 \mathrm{MPa}$ (PEREIRA; LOPES, 2011). On the other hand, in 'pau-de-jangada' (Apeiba tibourbou) seeds, Guedes et al. (2013) found that the highest germination speed index occurred at the highest temperature (35 ${ }^{\circ} \mathrm{C}$ ), and that the lowest reduction due to the low water availability occurred at temperature of $25^{\circ} \mathrm{C}$.
As observed in germination, the reduction of water availability in the substrate, caused by the increase in PEG 6000 concentration, led to reduction in shoot and root lengths of $S$. hispanica seedlings at all studied temperatures (Figure 1C and D). However, water stress effect on shoot and root lengths increased as temperature increased, with a satisfactory growth of the seedlings up to the level of $-0.1 \mathrm{MPa}$, for seeds germinated at temperatures of 20 and $25^{\circ} \mathrm{C}$. However, from this level on, there were drastic growth reductions $(>40 \%$ for shoot length and $>30 \%$ for root length) in seedlings grown from seeds germinated at temperatures of 30 ${ }^{\circ} \mathrm{C}$ and $20-30{ }^{\circ} \mathrm{C}$. In addition, at the osmotic potentials of -0.3 and $-0.4 \mathrm{MPa}$, higher primary root protrusion and lower shoot emergence were observed, which may be related to the tolerance mechanism of the species, increasing root growth in search of water in the substrate.

For the total dry matter of the seedlings, there was significant influence only of the osmotic potentials, which led a quadratic fit of the data. Dry matter accumulation decreased until the fitted level of $-0.37 \mathrm{MPa}$, with reduction of $92 \%$ in comparison to the control $(0.0 \mathrm{MPa})$ (Figure 2). These results indicate that the reduction in water availability in the sowing phase led to irreversible stress on the seeds, affecting the transfer of reserves to the seedlings, which suggests that $S$. hispanica seedlings are sensitive to the reduction of water availability in the substrate during sowing. Similar results were also observed by Guedes et al. (2013), who found that the dry matter content of Apeiba tibourbou seedlings was affected by the different osmotic potentials and decreased from the potential of $-0.2 \mathrm{MPa}$ on, eventually becoming almost null at the osmotic potential of $-0.8 \mathrm{MPa}$.

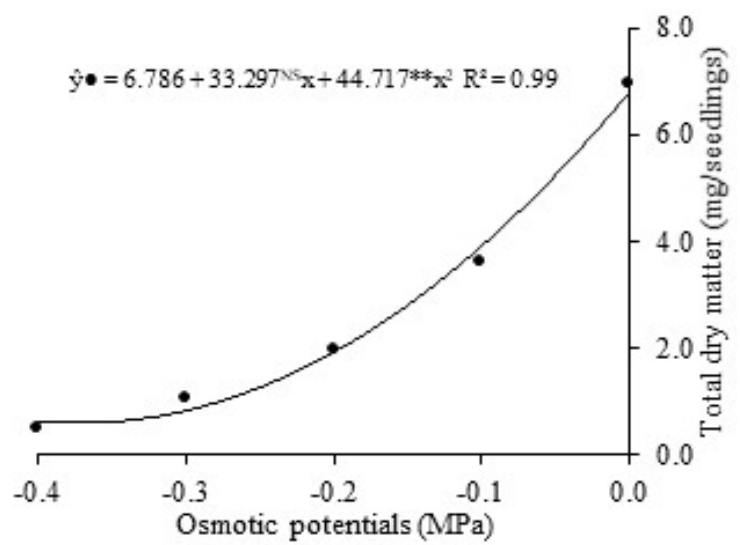

Figure 2. Total dry matter of chia (Salvia hispanica L.) seedlings subjected to different osmotic potentials induced by PEG $6000 .{ }^{\text {NS }}$ and $* *=$ not significant and significant at 0.01 probability level $(p<0.01)$, respectively 
The observed reductions in germination and growth of $S$. hispanica seedlings due to the reduction in the osmotic potential can be attributed to the decrease in the speed of metabolic and biochemical processes caused by water restriction, which delays or reduces seed germination and interferes with imbibition and cell elongation of the embryo. Additionally, it may reduce or prevent the emergence of primary root, through the alteration of the plasmatic membrane permeability, and the properties of the tonoplast, increasing the degradation of proteins, for stimulating the synthesis of proteolytic enzymes (YAMASHITA; GUIMARÃES, 2010). According to Taiz and Zeiger (2013), the first measurable effect of water stress is the reduction of growth, caused by the decrease in cell expansion, which requires adequate turgor potential. These results are coherent with those obtained by Kappes et al. (2010), who worked with maize seeds and observed that the PEG 6000 solution drastically reduced seedling length.

There was significant influence of the osmotic potentials on the contents of chlorophyll $a$, $b$ and carotenoids, with linear reductions of 6.12 , 4.17 and $1.39 \mathrm{mg} \mathrm{g}^{-1}$ per unit reduction in the osmotic potential, respectively (Figure $3 \mathrm{~A}, \mathrm{~B}$ and C). This pigment loss can derive from tilacoid membrane damage and direct oxidative pigment disintegration, inducing instability of the proteinpigment complexes at the reaction center. Since carotenoids are accessory pigments in the absorption and transfer of radiant energy, besides being protectors of chlorophyll in the photooxidation process, the reduction in chlorophyll contents is probably related to the decrease of its protectors. In addition, the reduction in the content of pigments may be related to the reduction in biomass accumulation and shoot growth.

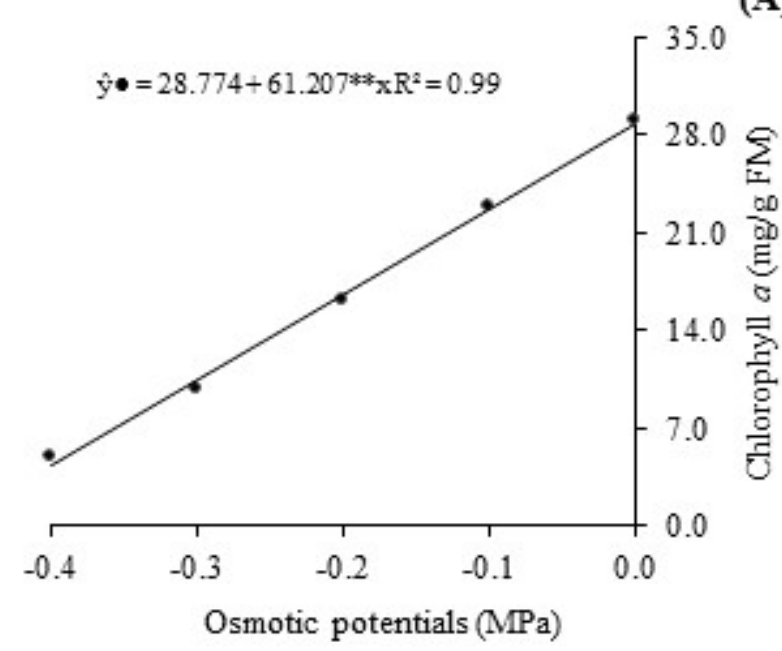

(A)
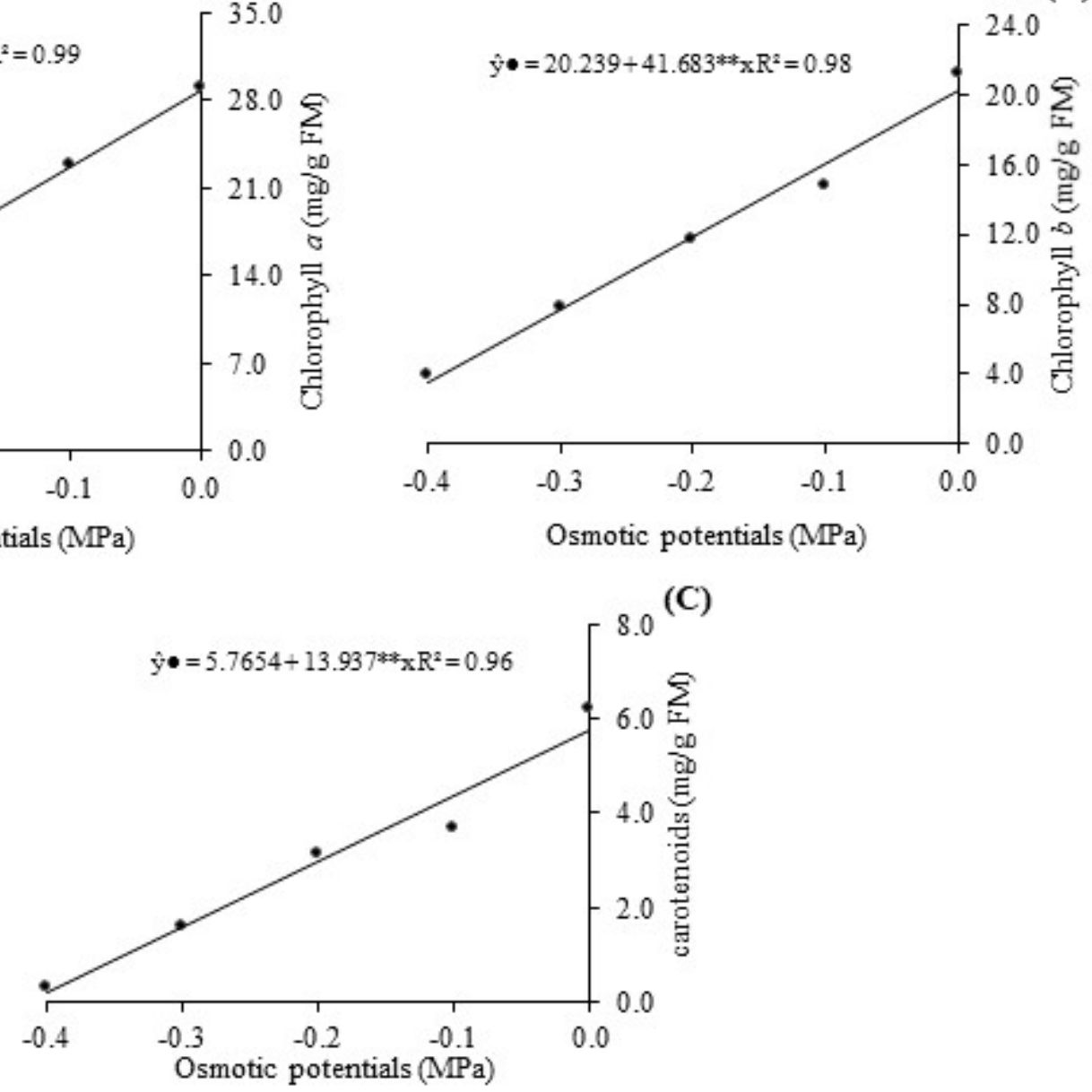

Figure 3. Contents of chlorophyll $a$ (A), chlorophyll $b$ (B) and carotenoids (C) in chia (Salvia hispanica L.) seedlings subjected to different osmotic potentials induced by PEG $6000 .{ }^{\mathrm{NS}} \mathrm{e}^{* *}=$ não significativo $\mathrm{e}$ significativo a $1 \%$ de probabilidade $(\mathrm{p}<0.01)$, respectivamente 
The variables chlorophyll $b$ and carotenoids were also significantly influenced by the different temperatures. As temperature increased, opposite responses occurred in chlorophyll $b$ and carotenoids contents; chlorophyll $b$ content increased whereas carotenoids content decreased with the increment of temperature (Figure $4 \mathrm{~A}$ and B). Seedlings from seeds germinated at $20{ }^{\circ} \mathrm{C}$ showed lower development compared with those from seeds germinated at the other temperatures, which was clearly observed in the control treatment $(0.0 \mathrm{MPa})$ (Figure 1C and D). The lower development of the seedlings in this treatment is related to the reduction of metabolic activity, caused by the low-temperature thermal stress (MARAGHNI; GORAI; NEFFATI, 2010; TAIZ; ZEIGER, 2013). According to Duarte (2003), when plants are subjected to some sort of stress, there is an increase in carotenoids content, reducing chlorophyll production, as observed in the present study.
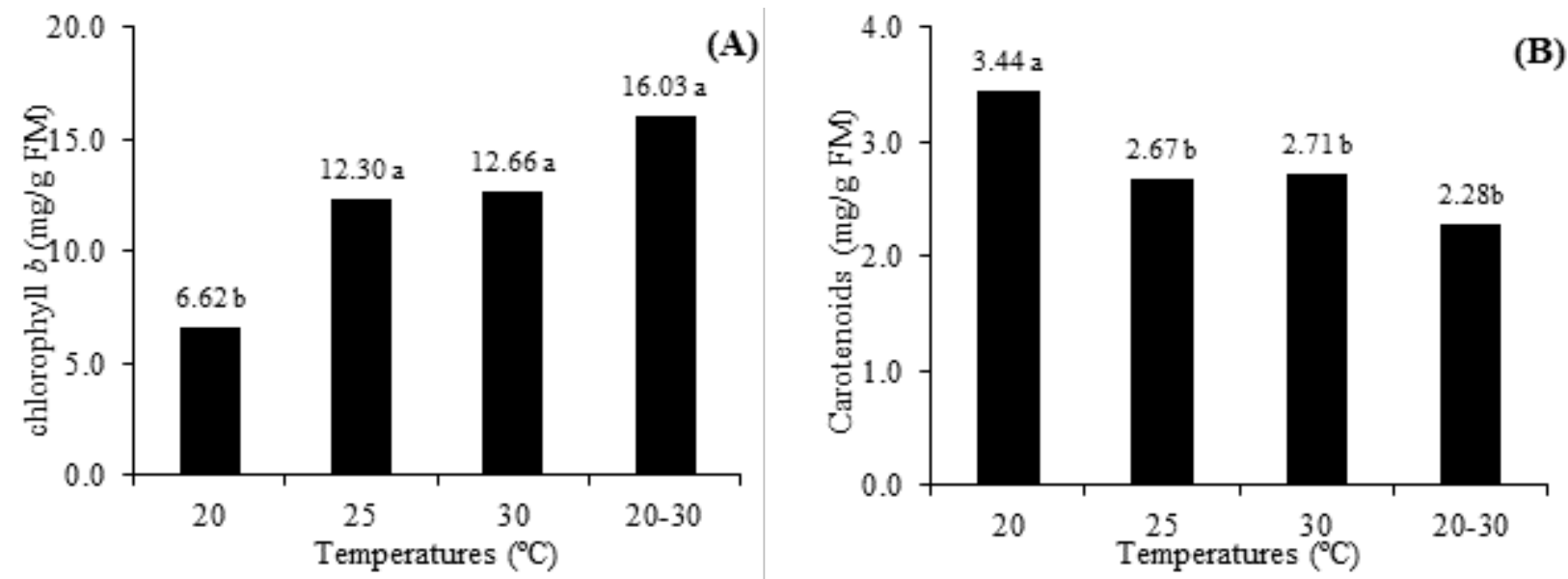

Figure 4. Contents of chlorophyll $b$ (A) and carotenoids (B) in chia (Salvia hispanica L.) seedlings subjected to different temperatures. Equal letters in the column do not differ by Tukey test $(p<0.05)$.

Amino acids contents showed a quadratic response in seedlings from seeds germinated at all temperatures, with the reduction in the PEG-6000induced osmotic potential. Highest contents were observed at osmotic potentials of $-0.16,-0.18,-0.23$ and $-0.13 \mathrm{MPa}$ for the constant temperatures of 20 , 25 and $30{ }^{\circ} \mathrm{C}$, and alternated temperature of $20-30$ ${ }^{\circ} \mathrm{C}$ (Figure 5A). Similar results were observed in proline contents, and highest values occurred at the osmotic potentials of $-0.15,-0.25,-0.31$ and -0.18 $\mathrm{MPa}$ for constant temperatures of 20,25 and $30^{\circ} \mathrm{C}$ and alternated temperature of $20-30{ }^{\circ} \mathrm{C}$ (Figure 5B). It is possible to observe that the increase of temperature significantly influenced the increment in proline contents and, consequently, the contents of total amino acids, allowing higher synthesis of these compounds at higher levels of osmotic potential.

Based on the correlation of proline and amino acids contents with growth data, it is observed that, at temperature of $25{ }^{\circ} \mathrm{C}$, the increments in these contents were consistent with the growth responses of the seedlings because, under water stress conditions, they showed higher growth in comparison to the other temperatures, denoting an efficient osmotic adjustment. Nevertheless, at temperature of $30{ }^{\circ} \mathrm{C}, \mathrm{S}$. hispanica seedlings also synthesized proline and amino acids up to high levels of osmotic potentials, but such increment does not corroborate the growth responses, which indicates that the synthesis of these compounds under this condition is related to the intensification of water stress by the increase of temperature.

For the contents of sugars in S. hispanica seedlings, a quadratic response was observed due to the reduction in the PEG-6000-induced osmotic potential at all temperatures evaluated. The highest contents of sugars occurred at osmotic potentials of $-0.26,-0.16,-0.18$ and $-0.21 \mathrm{MPa}$ for the constant temperatures of 20,25 and $30^{\circ} \mathrm{C}$, and alternated temperature of $20-30{ }^{\circ} \mathrm{C}$ (Figure $5 \mathrm{C}$ ). The synthesis of sugars by $S$. hispanica seedlings differed from the synthesis of amino acids, with higher values in plants subjected to low temperature conditions (20 ${ }^{\circ} \mathrm{C}$ or $20-30{ }^{\circ} \mathrm{C}$ ). In the correlation with growth data, it is possible to observe that the increase in the synthesis of sugars in seedlings from seeds germinated at temperature of $20{ }^{\circ} \mathrm{C}$ helped in the osmotic adjustment and, consequently, in shoot growth up to the level of $-0.3 \mathrm{MPa}$. However, at temperature of $20-30{ }^{\circ} \mathrm{C}$, the increase in the contents of sugars did not lead to gains in growth, which indicates that this synthesis is related to the increase 
in water stress stimulated by the temperature of 30

${ }^{\circ} \mathrm{C}$, as evidenced for proline and amino acids.
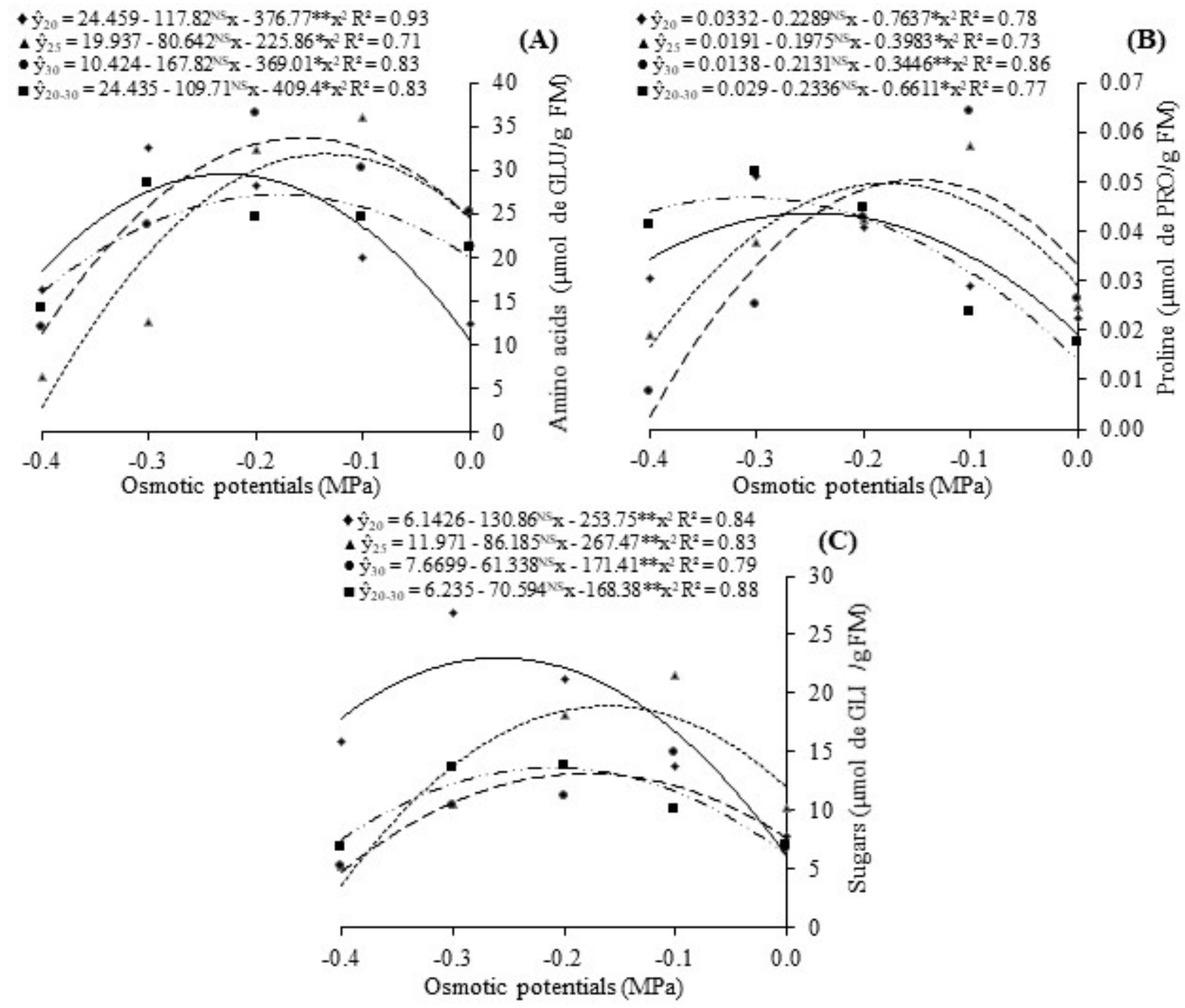

Figure 5. Contents of amino acids (A), proline (B) and sugars (C) in chia (Salvia hispanica L.) seedlings subjected to different PEG-6000-induced osmotic potentials and temperatures. ${ }^{\mathrm{NS}}$ and $* *=$ not significant and significant at 0.01 probability level $(\mathrm{p}<0.01)$. respectively.

Regarding the synthesis of osmolytes, in general, $S$. hispanica seedlings increased the contents of proline, free amino acids and sugars under water stress conditions, considering that these compounds accumulate as compatible solutes to stabilize membranes and maintain the conformation of proteins, which prevents cytosol dehydration (SZABADOS et al., 2011; TAIZ; ZAIGER, 2013). However, this osmotic adjustment was only effective when the seeds of $S$. hispanica seedlings germinated at temperatures of up to $25^{\circ} \mathrm{C}$.

\section{CONCLUSIONS}

Polyethylene glycol level of $-0.4 \mathrm{MPa}$ for all studied temperatures, and $-0.3 \mathrm{MPa}$ at temperatures of $30{ }^{\circ} \mathrm{C}$ and $20-30{ }^{\circ} \mathrm{C}$ inhibited germination and vigor in $S$. hispanica seedlings.

S. hispanica seedlings are able to perform osmotic adjustment under water stress conditions of up to $-0.3 \mathrm{MPa}$, when grown from seeds germinated at temperatures of up to $25^{\circ} \mathrm{C}$.

\section{ACKNOWLEDGMENTS}

The authors thank the Coordenação de Aperfeiçoamento de Pessoal do Ensino Superior CAPES. 
RESUMO: As sementes de $S$. hispanica têm se destacado pela sua potencialidade em nutrientes para as indústrias agroalimentares. No entanto, ainda são escassas as pesquisas relacionadas a esta espécie, principalmente no tocante aos fatores agronômicos que viabilizem a sua propagação e desenvolvimento. Com isso, objetivou-se verificar a germinação, vigor e ajustamento osmótico de sementes e plântulas de $S$. hispanica submetidas aos estresses hídrico e térmico. O delineamento experimental foi o inteiramente casualizado, com tratamentos distribuídos em esquema fatorial, correspondente a cinco níveis de polietileno glicol (PEG 6000) $(0,0 ;-0,1 ;-0,2 ;-0,3$ e $-0,4 \mathrm{MPa})$ e quatro temperaturas $\left(20,25,30\right.$ e $\left.20-30{ }^{\circ} \mathrm{C}\right)$, com quatro repetições de 50 sementes para cada tratamento. Para isso, instalou-se o teste de germinação em substrato mata-borrão, umedecidos com soluções de PEG 6000 nos potenciais mencionados, sob fotoperíodo de 8 horas de luz. As variáveis analisadas foram germinação, índice de velocidade de germinação, comprimento de parte aérea e das raízes das plântulas, massa seca de plântulas, teores de clorofila e carotenoides, aminoácidos, prolina e açúcares. O nível de polietilenoglicol de $-0,4 \mathrm{MPa}$ para todas as temperaturas estudadas, e $-0,3 \mathrm{MPa}$ nas temperaturas de $30{ }^{\circ} \mathrm{C}$ e $20-30{ }^{\circ} \mathrm{C}$ inviabilizam a germinação e o vigor das plântulas de $S$. hispanica. As plântulas de $S$. hispanica são capazes de realizar ajuste osmótico sob condições de estresse hídrico até os níveis de $-0,3 \mathrm{MPa}$, quando provenientes de sementes germinadas em temperaturas de até $25^{\circ} \mathrm{C}$.

PALAVRAS-CHAVE: Chia. Polietilenoglicol. Estresse abiótico. Viabilidade.

\section{REFERENCES}

ÁVILA, M. R.; BRACCINI, A. L.; SCAPIM, C. A.; FAGLIARI, J. R.; SANTOS, J. L. Influência do estresse hídrico simulado com manitol na germinação de sementes e crescimento de plântulas de canola. Revista Brasileira de Sementes, v.29, n.1, p.98-106, 2007. http://dx.doi.org/10.1590/S0101-31222007000100014

BATES, L. S.; WALDREN, R. P.; TEARE, I. D. Rapid determination of free proline for water-stress studies. Plant and Soil, v.39, n.2, p.205-207, 1973. https://doi.org/10.1007/BF00018060

BEWLEY, J. D.; BRADFORD, K. J.; HILHORST, H. W. M.; NONOGAKI, H. Seeds: Physiology of development, germination and dormancy. 3.ed. New York: Springer, 2013. 392p.

https://doi.org/10.1007/978-1-4614-4693-4

BRASIL. Ministério da Agricultura, Pecuária e Abastecimento. Regras para análise de sementes. Ministério da Agricultura, Pecuária e Abastecimento. Secretaria de Defesa Agropecuária. Brasília, DF: MAPA/ACS, 2009, 399p.

CARVALHO, N. M.; NAKAGAWA, J. Sementes: ciência, tecnologia e produção. 5. ed. Jaboticabal: FUNEP, 2012. 588p.

DUARTE, Carlos Henrique. Detecção óptica da eficiência quântica da fotossíntese. 109f. Dissertação (Mestrado em Engenharia Elétrica). Curso de Pós-Graduação em Engenharia Elétrica, Universidade Federal de Pernambuco, Recife, 2003.

FERREIRA, D. F. Sisvar: a computer statistical analysis system. Ciência e Agrotecnologia, v.35, n.6, p.10391042, 2011. http://dx.doi.org/10.1590/S1413-70542011000600001

GHADERI-FAR, F.; GHEREKHLOO, J.; ALIMAGHAM, M. Inluence of environmental factors on seed germination and seedling emergence of yellow sweet clover (Melilotus oicinalis). Planta Daninha, v.28, n.3, p.436-469, 2010. http://dx.doi.org/10.1590/S0100-83582010000300002

GORAI, M.; GASMI, H.; NEFFATI, M. Factors influencing seed germination of medicinal plant Salvia aegyptiaca L. (Lamiaceae). Saudi Journal of Biological Sciences, v.18, n.3, p.255-260, 2011. http://dx.doi.org/10.1016/j.sjbs.2011.01.004 
GUEDES, R. S.; ALVES, E. U.; VIANA, J. S.; GONÇALVES, E. P.; LIMA, C. R.; SANTOS, S. R. N. Germinação e vigor de sementes de Apeiba tibourbou submetidas ao estresse hídrico e diferentes temperaturas. Ciência Florestal, v.23, n.1, p.45-53, 2013. http://dx.doi.org/10.5902/198050988438.

KAPPES, C.; ANDRADE, J. A. C.; HAGA, K. I.; FERREIRA, J. P.; ARF, M. V. Germinação, vigor de sementes e crescimento de plântulas de milho sob condições de déficit hídrico. Scientia Agraria, v.11, n.2, p.125-134, 2010. https://doi.org/10.5380/rsa.v11i2.16464

LABOURIAU, L. G.; AGUDO, M. On The Physiology of Seed-Germination in Salvia hispanica L. I. Temperature Effects. Anais da Academia Brasileira de Ciências, v.59, n.2, p.37-56, 1987.

LICHTHENTHALER, H. K. Chlorophylls and carotenoids: pigments of photosynthetic biomembranes. In: PACKER, L.; DOUCE, R. (org.). Methods in Enzimology. London: Academic Press, 1987. p.350-382. https://doi.org/10.1016/0076-6879(87)48036-1

MARAGHNI, M.; GORAI, M.; NEFFATI, M. Seed germination at different temperatures and water stress levels, and seedling emergence from different depths of Ziziphus lotus. South African Journal of Botany, v.76, n.3, p.453-459, 2010. https://doi.org/10.1016/j.sajb.2010.02.092

MARCOS FILHO, J. Fisiologia de sementes de plantas cultivadas. 2 ed. Londrina: ABRATES, 2015. 659p. MUÑOZ, L. A.; COBOS, A.; DIAZ, O.; AGUILERA, J. M. Chia Seeds: Microstructure, Mucilage Extraction and Hydration. Journal of Food Engineering, v.108, n.1, p.216-224, 2012.

http://dx.doi.org/10.1016/j.jfoodeng.2011.06.037

(ANO DA REFERENCIA NÃO BATE COM O ANO CITADO NO TEXTO)

NASCIMENTO, W. M. Condicionamento osmótico de sementes de hortaliças visando a germinação em condições de temperaturas baixas. Horticultura Brasileira, v.23, n.2, p.211-214, 2005.

https://doi.org/10.1590/S0102-05362005000200010

PEREIRA, M. D.; LOPES, J. C. Germinação e desenvolvimento de plântulas de pinhão manso sob Condições de estresse hídrico simulado. Semina: Ciências Agrárias, v.32, n.1, p.1837-1842, 2011.

https://doi.org/10.5433/1679-0359.2011

SILVA JR, J. F.; KLAR, A. E.; TANAKA, A. A.; SILVA, I. P. F.; CARDOSO, A. E. I.; PUTTI, F. F. Tomato seeds vigor under water or salt stress. Brazilian Journal of Biosystems Engineering, v.8, n.1, p. 65-72, 2014. http://dx.doi.org/10.18011/bioeng2014v8n1p65-72

SILVA, M. S. A.; YAMASHITA, O. M.; SOUZA, M. D. A.; FERREIRA, D. A. T.; FELITO, R. A. Fatores ambientais na germinação de sementes de Barbarea verna. Enciclopédia Biosfera, v.10, n.18, p.1746-1759, 2014. https://doi.org/10.13140/rg.2.2.13725.31202

STEFANELLO, R.; GARCIA, D. C.; MENEZES, N. L.; MUNIZ, M. F. B.; WRASSE, C. F. Efeito da luz, temperatura e estresse hídrico no potencial fisiológico de sementes de funcho. Revista Brasileira de Sementes, v.28, n.2, p.135-141, 2006. http://dx.doi.org/10.1590/S0101-31222006000200018.

SZABADOS, L.; KOVÁCS, H.; ZILBERSTEIN, A.; BOUCHEREAU, A. Plants in extreme envi-ronments: importance of protective compounds in stress tolerance. Advances in Botanical Research, v.57, n.1, p.105150, 2011. http://dx.doi.org/10.1016/B978-0-12-387692-8.00004-7

TAIZ, L.; ZEIGER, E. Fisiologia vegetal. 5.ed. Porto Alegre: Artmed, 2013. 954 p.

VILLELA, F. A.; DONI FILHO, L.; SEQUEIRA, E. L. Tabela de potencial osmótico em função da concentração de polietilenoglicol 6000 e da temperatura. Pesquisa Agropecuária Brasileira, v.26, n.11, p.1957-1968, 1991. 
YAMASHITA, O. M.; GUIMARÃES, S. C. Germinação das sementes de Conyza canadensis e Conyza bonariensis em função da disponibilidade hídrica no substrato. Planta Daninha, v.28, n.2, p.309-317, 2010. http://dx.doi.org/10.1590/S0100-83582010000200010

YEMM, E. W.; COCCKING, E. C. The determination of amino acid with ninhydrin. Analyst, v.80, n.2, p. 209213, 1955. https://doi.org/10.1039/an9558000209

YEMM, E.W.; WILLIS, A. J. The estimation of carbohydrates in plant extracts by anthrone. Biochemical Journal, v.57, n.3, p.508-514, 1954. https://doi.org/10.1042/bj0570508 